\title{
PENDEKATAN BUDAYA KERJA UNTUK MENGURANGI KETIDAKSELARASAN ANTAR DIVISI PADA BATIK BOGOR TRADISIKU
}

\author{
Lisha Luthfiana Fajri ${ }^{* 1}$, Syamsul Maarif**), dan Ujang Sumarwan ${ }^{* *}$ \\ *) Batik Bogor Tradisiku \\ J1. Jalak No.2 Tanah Sareal, Kota Bogor 16161 \\ **) Sekolah Bisnis, Institut Pertanian Bogor \\ Jl. Raya Pajajaran, Bogor 16151 \\ $\left.{ }^{* * *}\right)$ Departemen Ilmu Keluarga dan Konsumen, Fakultas Ekologi Manusia, Institut Pertanian Bogor \\ Jl. Lingkar Akademik, Kampus IPB Dramaga, Bogor 16680
}

\begin{abstract}
Organization or company conformity is a degree of collaboration among the structure, strategy, and culture. Thus, culture is classified into the following four aspects i.e. family (clan), innovative creation (adhocracy), hierarchy, and the market. This study intended to validate whether the power relationship and leadership can become catalysts to accelerate the formation of organizational uniformity. Hence, this study also aimed to identify the organizational culture approach suitable to be applied in Bogor Batik Tradisiku in order to reduce the unconformity occurring among divisions, observe the cultural influence, relationship strength and leaderships toward conformity, and to explain them through the managerial implications. These causal relationships were analyzed by utilizing Structural Equation Modelling (SEM) with Partial Least Squares (PLS) approach to perform the level-two confirmatory factor analysis. The results showed that Bogor Batik Tradisiku is urged to implement the organizational culture approach of Adhocracy to replace the clan which was supported by an appropriate leadership style to accelerate the presence of company conformity.
\end{abstract}

Keywords: conformity, company culture, power relationship, leadership, SEM, PLS

\begin{abstract}
ABSTRAK
Keselarasan organisasi atau perusahaan adalah derajat kolaborasi antara struktur, strategi, dan budaya. Selanjutnya, budaya akan dibagi ke dalam empat aspek, yaitu aspek kekeluargaan (clan), kreasi inovasi (Adhocracy), hierarki (hierarchy), dan pasar (market). Kemudian, penelitian ini akan membuktikan apakah kekuatan pertalian (Power Relationship) dan kepemimpinan (Leadership) dapat menjadi katalis yang mempercepat terbentuknya keselarasan organisasi. Penelitian ini bertujuan mencari jenis pendekatan budaya kerja yang cocok untuk diterapkan di Batik Bogor Tradisiku untuk mengurangi terjadinya ketidakselarasan antar divisi, melihat pengaruh dari budaya, kekuatan pertalian, dan kepemimpinan terhadap keselarasan dan menjelaskan melalui implikasi manajerial. Hubungan sebab akibat ini dianalisis menggunakan Structural Equation Modelling (SEM) dengan pendekatan Partial Least Squares (PLS) untuk confirmatory factor analysis tingkat dua. Hasil penelitian menunjukkan bahwa Batik Bogor Tradisiku perlu melakukan pendekatan budaya kerja Adhocracy untuk menggantikan clan, dan didukung dengan leadership style yang tepat akan mempercepat terciptanya keselarasan dalam perusahaan.
\end{abstract}

Kata kunci: keselarasan, budaya perusahaan, kekuatan pertalian, kepemimpinan, SEM, PLS

${ }^{1}$ Alamat Korespondensi:

Email: lisha.luthfiana@gmail.com

\section{PENDAHULUAN}

Perekonomian Indonesia selalu menarik untuk diteliti dan diperbincangkan. Negara kepulauan terbesar di dunia ini memiliki tantangan tersendiri dalam mengatur kegiatan ekonominya dari Sabang sampai Merauke, dan dari sektor bisnis kelas kakap hingga sektor mikro, kecil, dan menengah. Komoditas yang dijajakan pun beraneka ragam, baik berupa barang maupun jasa.
Kegiatan ekonomisaatini sudahmenujuarah globalisasi, dunia sudah memasuki era pertumbuhan pasar (market) yang sangat cepat, sehingga organisasi atau perusahaan perlu melakukan inovasi berkelanjutan agar dapat bertahan (Dixit dan Nanda, 2011). Oleh karena itu, dalam menghadapi Masyarakat Ekonomi ASEAN (MEA) di akhir 2015, Indonesia sudah mempersiapkan diri melalui berbagai lini, termasuk sektor Industri Kecil Menengah (IKM). Pimpinan dari tiap IKM harus 
bisa memberi warna pada budaya perusahaan dengan memperhatikan potensi dari nilai-nilai yang dimiliki oleh karyawannya (Inabinett, 2010).

Sektor IKM semakin populer dalam perekonomian Indonesia sejak krisis moneter 1997 karena kedudukannya tetap bertahan dibandingkan industri besar, bahkan menjadi penyokong pertumbuhan ekonomi nasional. Salah satu kebijakan pemerintah saat ini untuk mendukung IKM, yaitu One Village One Product (OVOP) dan sudah mulai dirintis di Kota Bogor. Komoditas yang sudah mulai diterapkan pada OVOP di Bogor yaitu sulam, daur ulang limbah, dan juga batik.

Pada akhir 2010, IKM yang bergerak di bidang batik di Indonesia tercatat berjumlah 55.778 unit dengan penyerapan tenaga kerja sebesar 916.783 orang dan nilai produksi mencapai Rp 3,941 triliun dengan total ekspor mencapai US\$ 123 juta (Jusri dan Idris, 2011). Di sisi lain, IKM batik masih memiliki keterbatasan eksternal seperti masih adanya pengaturan harga pembelian yang dikuasai oleh pihak tertentu dan adanya keterbatasan Sumberdaya Manusia (SDM) di sisi internal. Sejatinya, dengan komunikasi yang efektif antar divisi, kegiatan perusahaan secara keseluruhan dapat berjalan dengan baik, namun tak ayal terjadi ketidakselarasan antar divisi. Keselarasan sebuah organisasi atau perusahaan (organizational Alignment) adalah hal baru namun merupakan isu yang berkembang sangat cepat. Pendekatan kepemimpinan juga dapat membantu dalam mencapai keselarasan, kuncinya dengan menjaga kendali agar terpusat pada inti dan mengaturnya sebagai aset strategis bagi perusahaan (Farquhar, 2005).

Batik Bogor Tradisiku (BBT) adalah pelopor batik di Kota Bogor sejak 13 Januari 2008. BBT merupakan IKM batik yang mengintegrasikan Workshop, galeri, dan Lembaga Kursus dan Pelatihan (LKP) pada satu lokasi, sedangkan tiga divisi utama yang ada di BBT yaitu produksi batik hingga ke produk turunannya, LKP, dan Mozaik Batik yang mengaplikasikan perca batik pada media keramik atau gerabah sehingga zero waste. Keadaan yang tengah terjadi sekarang dengan adanya tiga divisi utama tersebut diantaranya adalah terjadinya ketidakselarasan antar karyawan lintas divisi yang menyebabkan cacat hasil produksi, pelayanan kurang prima, dan dapat berakibat pada menurunnya kepuasan pada konsumen tertentu.
Setelah BBT dijadikan objek wisata budaya, keselarasan menjadi fokus perhatian perusahaan dalam memberikan produk dan jasa yang memuaskan kepada para konsumen, dan budaya menjadi salah satu sorotan yang dapat berpengaruh pada maju atau mundurnya perusahaan selain karena faktor teknis. Oleh karena itu, pada penelitian ini penulis akan melihat apakah intervensi budaya berpengaruh pada proses terciptanya keselarasan (alignment). Selain itu, akan dilihat juga bagaimana leadership dan power relationship dapat membantu tercapainya keselarasan dengan lebih cepat. Kemudian, akan diteliti bagaimana mengimplementasikan perbaikannya melalui pendekatan perubahan budaya kerja agar tercipta kondisi keselarasan.

Berdasarkan kondisi tersebut maka tujuan daripenelitian ini, yaitu mengidentifikasi dan menganalisis budaya kerja di BBT yang dapat menyebabkan terjadinya ketidakselarasan antar divisi; menganalisis hubungan antara ketidakselarasan antar divisi di BBT dengan kepuasan pelanggan; dan memformulasikan strategi perubahan budaya kerja di BBT untuk mengurangi terjadinya ketidakselarasan antar divisi.

\section{METODE PENELITIAN}

Penelitian ini dilakukan di galeri Batik Bogor Tradisiku yang beralamat di Jl. Jalak No,2 Tanah Sareal, Kota Bogor. Pengambilan data dimulai pada bulan September sampai Oktober 2015 dengan menggunakan instrumen berupa angket atau kuesioner yang akan diisi oleh seluruh karyawan di semua divisi (sensus).

Dengan berangkat dari teori mengenai keselarasan, kemudian menuju data dari hasil hasil sensus, penelitian ini akan berakhir pada penerimaan atau penolakan teori yang telah disampaikan sebelumnya. Analisis penelitian ini menjelaskan keterkaitan antara faktor keselarasan dari sisi budaya kerja di perusahaan. Akan dilihat pula apakah terdapat katalis yang dapat mempercepat terciptanya keselarasan pada perusahaan.

Data yang diperlukan dalam penelitian ini berasal dari dua sumber, yaitu data primer dan data sekunder. Data primer diperoleh dari hasil sensus karyawan di BBT (Tabel 1), sedangkan data sekunder diperoleh dari kajian terhadap studi pustaka seperti literatur dan referensi yang dimaksudkan untuk menunjang penelitian 
termasuk penelitian sebelumnya di BBT. Penelitian ini menggunakan teknik sensus, karena narasumber untuk penelitian ini adalah populasi karyawan tetap di BBT yang berjumlah tiga puluh orang dan mewakili seluruh divisi.

Pada kuesioner, digunakan skala Likert 1-5. Skala Likert ini digunakan sebagai alat untuk mengukur butir-butir pertanyaan pada kuesioner dengan pilihan yang berjenjang. Skala ini juga menggambarkan ukuran kesetujuan dan ketidaksetujuan seseorang terhadap suatu objek. Adapun jenjang yang digunakan pada kuesioner penelitian ini adalah $1=$ sama sekali tidak setuju, 2 = kurang setuju, $3=$ netral antara setuju dan tidak, $4=$ setuju, dan $5=$ sangat setuju.

Isi pertanyaan pada kuesioner ditujukan untuk mengidentifikasi adanya perubahan yang terjadi pada perusahaan. Tahap berikutnya adalah mengidentifikasi adanya ketidakselarasan dalam perusahaan. Tahap terakhir adalah mengidentifikasi gejalanya dan membangun proses perubahan atau perbaikannya (Lundin dan Norman, 2010).

Penggunaan analisis kualitatif deskriptif pada penelitian ini membuat penyajian data lebih mudah dalam memahami fenomena yang dialami oleh subjek penelitian dengan cara deskriptif dalam bentuk katakata dan bahasa pada suatu konteks. Data ini berupa keterangan-keterangan seperti sejarah perusahaan, perencanaan, serta strategi yang dilakukan untuk memasarkannya (Kolina dan Mustamu, 2013). Pekerjaan analisis data dalam hal ini ialah mengatur, mengurutkan, dan mengelompokan.
Penelitian ini dilanjutkan dengan menggunakan SEM dengan pendekatan Partial Least Squares (PLS) karena tidak menuntut sampel dalam jumlah besar dan direkomendasikan antara 30-100 kasus seperti yang dipaparkan dalam Ghozali (2015). Evaluasi model dalam SEM-PLS menggunakan program SmartPLS 3.0 dengan menilai hasil pengukuran model melalui confirmatory factor analysis (CFA) dengan evaluasi model struktural (inner model) dengan menguji validitas dan reabilitas konstruk laten dan dilanjutkan evaluasi model pengukuran (outer model) dengan uji signifikansi dan metode resampling dengan bootstrapping untuk menguji pengaruh antar konstruk atau variabel. Model awal SEM-PLS yang diujikan pada penelitian ini dapat dilihat pada Gambar 1. Pada penelitian ini, hipotesis yang diujikan adalah sebagai berikut:

H0 : variabel tidak berpengaruh nyata

H1 : variabel culture berpengaruh nyata terhadap alignment

H2 : variabel clan berpengaruh nyata terhadap culture dalam alignment

H3 : variabel adhocracy berpengaruh nyata terhadap culture dalam alignment

H4 : variabel hierarchy berpengaruh nyata terhadap culture dalam alignment

H5 : variabel market berpengaruh nyata terhadap culture dalam alignment

H6 : variabel leadership berpengaruh nyata terhadap alignment

H7 : variabel leadership berpengaruh nyata terhadap culture dalam alignment

H8 : variabel power relationship berpengaruh nyata terhadap alignment

H9 : variabel power relationship berpengaruh nyata terhadap culture dalam alignment

Tabel 1. Jumlah narasumber

\begin{tabular}{llc}
\hline \multicolumn{1}{c}{ Strata/lapisan } & \multicolumn{1}{c}{ Jabatan } & Jumlah populasi tiap strata \\
\hline Pimpinan perusahaan & Owner & 1 \\
Kepala divisi & Divisi SDM dan operasional & 1 \\
& Divisi keuangan & 1 \\
& Divisi produksi & 1 \\
& Divisi pemasaran & 1 \\
& LKP (Lembaga Kursus Pelatihan) & 1 \\
Karyawan & Staf divisi SDM dan operasional & 1 \\
& Staf divisi keuangan & 1 \\
& Staf divisi produksi & 12 \\
& Staf divisi pemasaran & 5 \\
& LKP & 5 \\
\hline
\end{tabular}




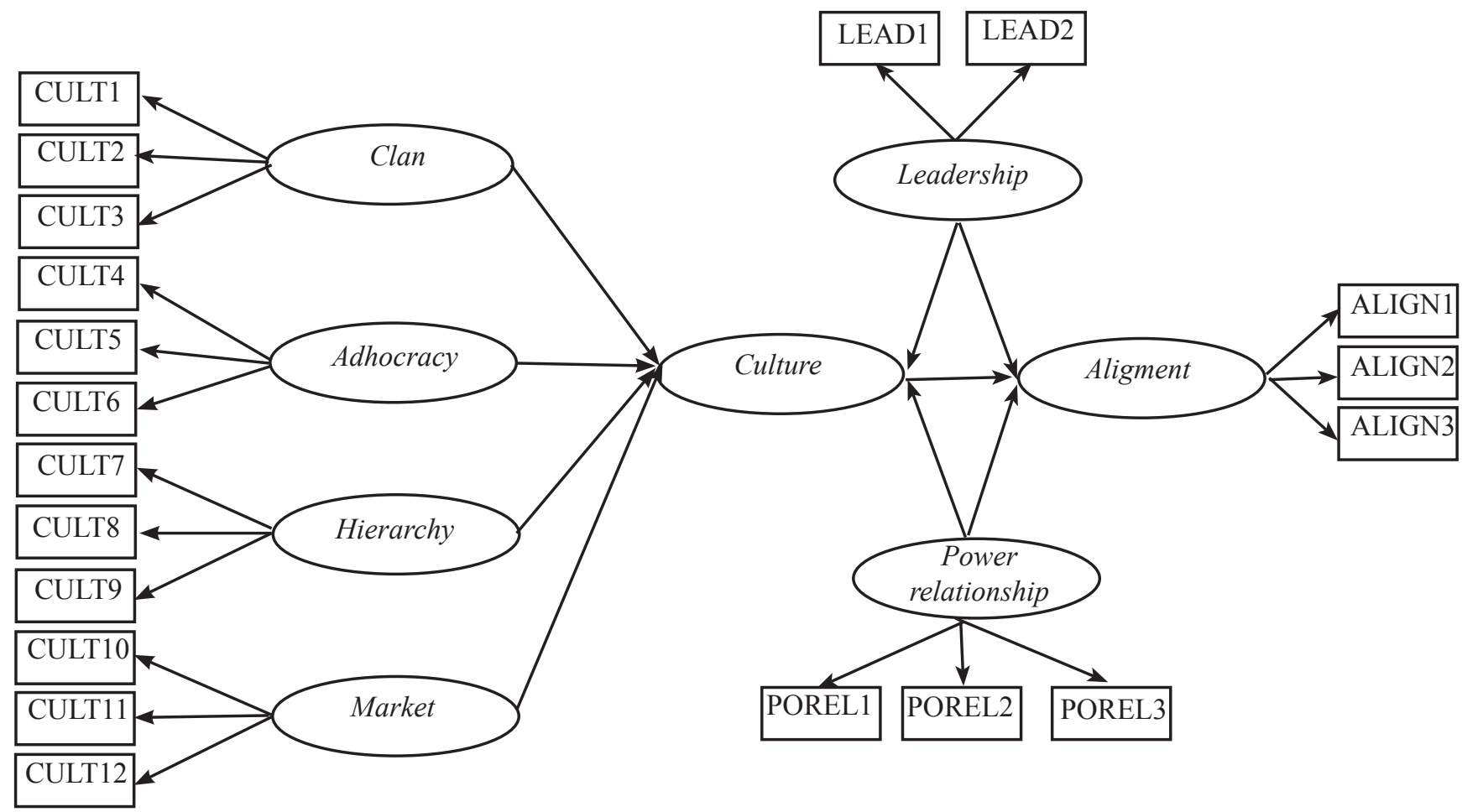

Gambar 1. Model awal pengujian SEM-PLS

Untuk setiap variabel laten memiliki beberapa indikator yang juga dipergunakan dalam menyusun pertanyaan pada kuesioner. Operasionalisasi variabel yang digunakan untuk mengolah data penelitian ini dijabarkan pada Tabel 2.

\section{HASIL}

\section{Analisis Deskriptif}

Analisis kualitatif deskriptif digunakan untuk menyajikan data agar lebih mudah dipahami mengenai fenomena yang dialami oleh subjek penelitian. Kemudian dilakukan analisis data, yaitu proses mencari dan menyusun secara sistematis data yang telah diperoleh. Hal ini bermaksud untuk mengorganisasikan data yang terkumpul dan biasanya cukup banyak, seperti catatan lapangan dan tanggapan peneliti, gambar, dokumen, artikel, dll. Pekerjaan analisis data dalam hal ini ialah mengatur, mengurutkan, mengelompokan, memberikan kode dan mengkategorisasikannya.
Tabel 2. Tabel operasionalisasi variabel

\begin{tabular}{|c|c|}
\hline Dimensi & Indikator \\
\hline \multirow{3}{*}{$\begin{array}{l}\text { Clan } \\
\text { culture }\end{array}$} & Teman kerja seperti keluarga (CULT1) \\
\hline & Kesetiaan (CULT2) \\
\hline & Pengembangan SDM (CULT3) \\
\hline \multirow{3}{*}{$\begin{array}{l}\text { Adhocracy } \\
\text { culture }\end{array}$} & Inovatif pada produk (CULT4) \\
\hline & Kebebasan dan keunikan (CULT5) \\
\hline & Berani ambil resiko (CULT6) \\
\hline \multirow{3}{*}{$\begin{array}{l}\text { Hierarchy } \\
\text { culture }\end{array}$} & Pemimpin sebagai koordinator (CULT7) \\
\hline & $\begin{array}{l}\text { Rasa aman dan stabilitas hubungan } \\
\text { (CULT8) }\end{array}$ \\
\hline & Peraturan dan kebijakan formal (CULT9) \\
\hline \multirow{3}{*}{$\begin{array}{l}\text { Market } \\
\text { culture }\end{array}$} & Pencapaian target (CULT10) \\
\hline & Prestasi (CULT11) \\
\hline & Kompetisi (CULT12) \\
\hline \multirow[t]{2}{*}{ Leadership } & Struktur organisasi (LEAD1) \\
\hline & Strategi kepegawaian (LEAD2) \\
\hline \multirow{3}{*}{$\begin{array}{l}\text { Power } \\
\text { relationship }\end{array}$} & Rewards (POREL1) \\
\hline & Lama bekerja (POREL2) \\
\hline & Komunikasi interpersonal (POREL3) \\
\hline \multirow[t]{3}{*}{ Alignment } & Desain organisasi (ALIGN1) \\
\hline & Strategi organisasi (ALIGN2) \\
\hline & Nilai dan norma organisasi (ALIGN3) \\
\hline
\end{tabular}


Narasumber pada penelitian ini yang berjumlah 30 orang digambarkan dengan beberapa kategori tertentu, seperti jenis kelamin, usia, status pernikahan, pendidikan terakhir, lama bekerja, dan pendapatan di luar gaji. Hasilnya dapat dilihat pada Gambar 2.

\section{Analisis Korelasi Karakteristik Narasumber dengan Culture, Leadership, Power Relationship, dan Alignment}

Penelitian ini menggunakan analisis korelasional untuk mengetahui kaitan antara karakteristik narasumber dengan variabel-variabel yang digunakan pada penelitian ini menggunakan program SPSS 16.0 dengan pendekatan analisis Spearman.

Hasil penelitian menunjukkan bahwa jenis kelamin, usia, pendidikan terakhir, dan pendapatan di luar gaji tidak memiliki korelasi dengan keempat aspek culture, leadership, power relationship, dan alignment. Akan tetapi, status pernikahan berpengaruh pada kekeluargaan (clan) dan lama bekerja berpengaruh pada reaksi pasar (market). Hasil uji korelasi antara karakteristik dan variabel dengan lengkap tersaji pada Tabel 3.

Selain itu, turut dicek korelasi dari masing-masing variabel. Clan, adhocracy, hierarchy, dan market saling berhubungan membentuk culture karena memiliki nilai signifikansi (p-value) lebih kecil dari galat 0,05 dengan uji dua arah (two-tails). Selain itu terdapat juga korelasi antara struktur organisasi dan strategi kepegawaian membentuk variabel leadership dan rewards, lama bekerja, dan komunikasi interpersonal membentuk power relationship.

Hasil uji korelasi dengan Spearman, karakteristik dari narasumber tidak terlalu berhubungan dengan variabel culture, leadership, power relationship, ataupun alignment. Akan tetapi, jika dilihat pada variabel clan, karakteristik seperti status pernikahan, lama bekerja, dan besarnya pendapatan di luar gaji memberikan kontribusi korelasi walaupun ada yang bersifat lemah maupun moderat. Hal ini menunjukkan bahwa budaya perusahaan yang sedang terjadi di BBT adalah budaya kekeluargaan, dengan sedikit pengaruh hierarchy dan orientasi market.

\section{Evaluasi Inner Model dan Outer Model}

Evaluasi model struktural (inner model) dilakukan dengan menguji validitas dan reabilitas. Uji validitas convergent dilihat dari nilai loading factor yang harus bernilai $>0,70$ untuk penelitian ini yang termasuk dalam jenis confirmatory research. Jika ada konstruk yang bernilai di bawah tersebut, maka harus dihilangkan seperti CULT1, CULT10, POREL5, POREL6, dan ALIGN2. Konstruk tersebut harus dihapus sehingga diperoleh nilai dari semua konstruk berada di atas 0,70 dan model penelitian ini dikatakan valid. Hasil yang diperoleh pada penelitian ini pada Gambar 3.

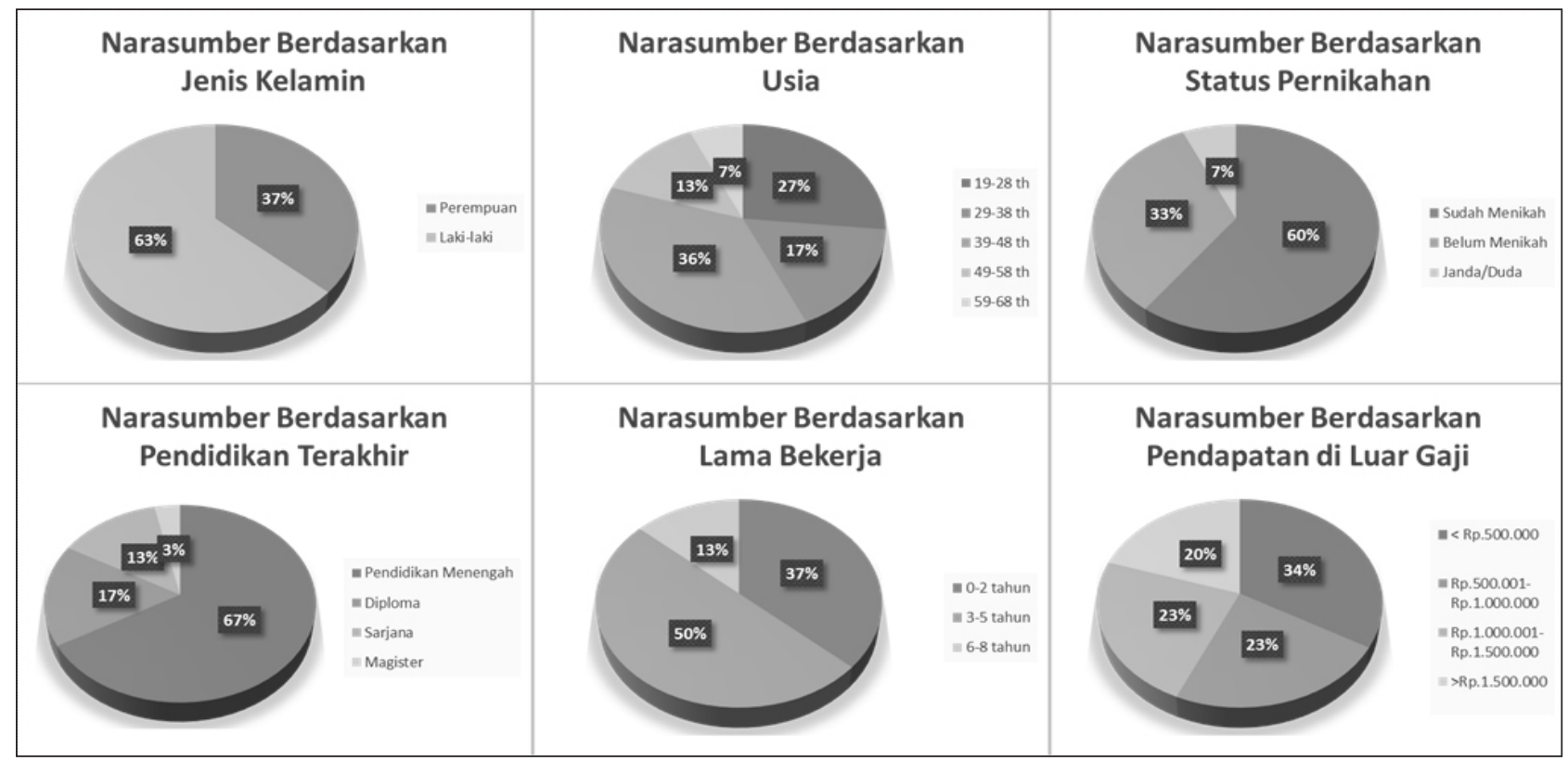

Gambar 2. Diagram karakteristik narasumber 
Tabel 3. Hasil uji korelasi karakteristik dengan variabel

\begin{tabular}{|c|c|c|c|c|c|c|c|}
\hline & & $\begin{array}{c}\text { Jenis } \\
\text { Kelamin }\end{array}$ & Usia & $\begin{array}{c}\text { Status } \\
\text { Pernikahan }\end{array}$ & $\begin{array}{c}\text { Pendidikan } \\
\text { Terakhir }\end{array}$ & $\begin{array}{c}\text { Lama } \\
\text { Bekerja }\end{array}$ & $\begin{array}{c}\text { Pendapatan } \\
\text { Luar Gaji }\end{array}$ \\
\hline \multirow[t]{3}{*}{ Culture } & Clan & Tidak & tidak & moderat & tidak & lemah & lemah \\
\hline & Adhocracy & tidak & tidak & tidak & tidak & tidak & tidak \\
\hline & Hierarchy & tidak & tidak & lemah & tidak & lemah & tidak \\
\hline \multirow[t]{3}{*}{ Leadership } & Market & lemah & tidak & tidak & tidak & moderat & tidak \\
\hline & Struktur Organisasi & tidak & tidak & tidak & tidak & lemah & tidak \\
\hline & Strategi Kepegawaian & tidak & tidak & tidak & tidak & tidak & tidak \\
\hline \multirow{3}{*}{$\begin{array}{l}\text { Power } \\
\text { Relationship }\end{array}$} & Rewards & tidak & tidak & tidak & tidak & tidak & tidak \\
\hline & Lama Bekerja & lemah & tidak & tidak & tidak & lemah & tidak \\
\hline & Komunikasi Interpersonal & tidak & lemah & tidak & tidak & tidak & tidak \\
\hline \multirow[t]{3}{*}{ Alignment } & Norma & tidak & tidak & tidak & tidak & tidak & tidak \\
\hline & Strategi & tidak & tidak & tidak & tidak & tidak & tidak \\
\hline & Struktur & tidak & tidak & tidak & tidak & tidak & tidak \\
\hline
\end{tabular}

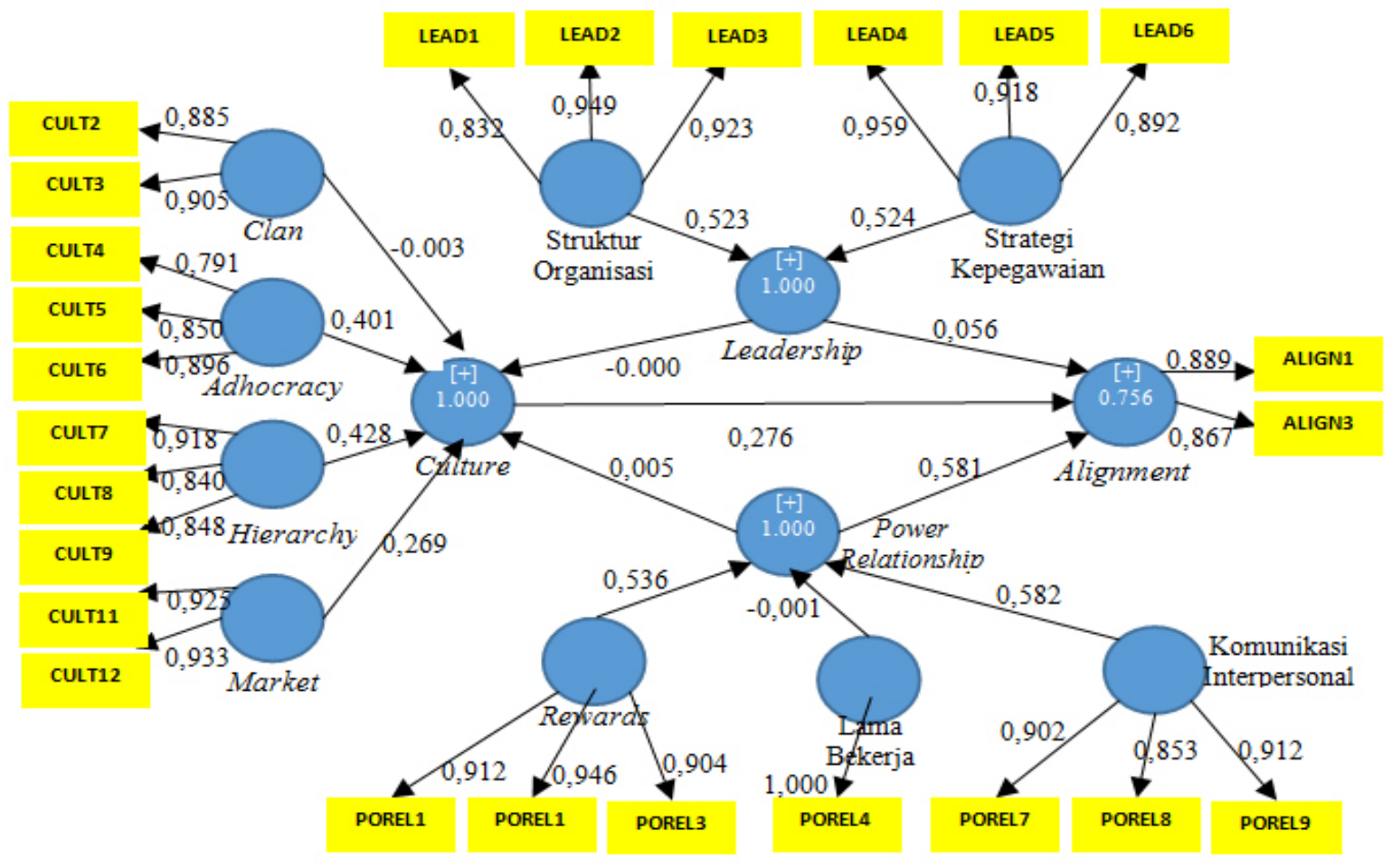

Gambar 3. Hasil pengujian convergent validity

Clan justru memberikan pengaruh negative. Namun, tidak signifikan terhadap culture. Adhocracy memberikan pengaruh 0,402 terhadap culture. Hierarchy memberikan pengaruh 0,428 terhadap culture, dan market memberikan pengaruh 0,269 terhadap culture. Jadi, pembentukan sebuah budaya perusahaan pada IKM BBT banyak dipengaruhi oleh pengembangan inovasi dan struktur perusahaan yang lebih jelas.

Uji berikutnya adalah uji validitas discriminant melalui nilai Average Variance Extracted (AVE) yang harus bernilai $>0,50$ untuk confirmatory research dan uji reabilitas melalui nilai Cronbach's Alpha dan Composite Reliability yang masing-masing harus bernilai $>0,70$ untuk confirmatory research. Hasil pengujian AVE, composite reliability, dan Cronbach's Alpha dapat dilihat pada Tabel 4.

Dalam menilai model struktural, juga dilakukan pengecekan nilai R-squares dan diperoleh 0,756 untuk Alignment. Nilai R-squares dari variable laten endogen ini $>0,75$ yang menunjukkan kekuatan prediksi dari model struktural. Nilai 0,756 merepresentasikan model sudah kuat dan 75,6\% variansi dari konstruk alignment dijelaskan oleh variabel culture, leadership, dan power 
relationship. Kemudian, dilakukan evaluasi model pengukuran (outer model), dilakukan uji bootstrapping yang merupakan metode resampling untuk mengetahui signifikansi dari estimasi parameter PLS yang tidak diketahui. Dari nilai path coefficients, terlihat pengaruh positif pembentukan variable alignment kecuali clan, lama bekerja, dan leadership.

\section{Analisis pengaruh Culture terhadap Alignment}

Hasil penelitian menunjukkan bahwa pada tingkat kepercayaan $95 \%(\alpha=5 \%)$, culture berpengaruh positif sebesar 0,276. Namun, kurang signifikan terhadap terbentuknya alignment, dengan nilai t-statistik sebesar 1,351 (lebih kecil dari t-tabel senilai 1,96). Dengan demikian H1 ditolak atau dengan kata lain culture tidak terlalu berpengaruh nyata terhadap alignment.

Jika lebih lanjut menganalisis pada empat aspek culture, hasil penelitian menunjukkan bahwa nilai t-statistik adhocracy, hierarchy, dan market, yaitu berturutturut 11,763; 10,637; 8,144 lebih besar dari t-tabel. Sebaliknya, dengan clan yang nilai t-statistiknya 0,567 dan koefisien parameternya $-0,003$. Dengan demikian H3, H4, dan H5 diterima sedangkan H2 ditolak. Dengan kata lain, aspek adhocracy, hierarchy, dan market berpengaruh nyata terhadap culture dalam membentuk alignment, sedangkan clan justru berpengaruh negatif.
Penelitian yang dilakukan Gerdhe (2012) menyatakan bahwa budaya dapat menjadi alat strategik demi tercapainya keselarasan sebuah perusahaan. Kemudian, dengan budaya digunakan sebagai sebuah alat dalam melakukan perubahan di perusahaan harus dapat menjawab sejauh mana budaya dijadikan indeks dari norma, nilai, dan pedoman dari setiap karyawan. Tentunya proses ini akan melibatkan etika dalam upaya melakukan perubahan budaya kerja (Awal et al. 2006). Selanjutnya, hal ini dapat menjadi pertimbangan bahwa titik kritis yang sedang terjadi di BBT adalah tidak tepatnya budaya clan sehingga perlu diatur dengan pendekatan adhocracy, berdasarkan nilai signifikansi pengaruh terbesar terhadap culture.

\section{Analisis pengaruh Leadership terhadap Alignment}

Hasil penelitian memberikan nilai koefisien parameter 0,0056 dan t-statistik 0,217 kepada leadership dalam memberikan kontribusinya terhadap alignment sehingga H6 ditolak. Hal ini berarti leadership sebenarnya berpengaruh positif terhadap alignment, tetapi tidak signifikan. Dilihat dari aspek struktur organisasi dan strategi kepegawaian, nilai koefisien parameternya 0,524 dan 0,523 serta t-statistik 22,889 dan 29,222. Sangat jelas terlihat bahwa kedua indikator ini berpengaruh positif dan sangat signifikan terhadap leadership. Hal ini sejalan dengan penelitian sebelumnya yang dilakukan oleh Dixit dan Nanda (2011) mengenai struktur organisasi dan strategi kepegawaian memengaruhi leadership.

Tabel 4. Hasil uji Average Variance Extrated, Composite Reliability, dan Cronbach's Alpha

\begin{tabular}{lccc}
\hline \multicolumn{1}{c}{ VARIABEL } & AVE & Composite reliability & Cronbach Alpha \\
\hline Adhocracy & 0,717 & 0,884 & 0,803 \\
Alignment & 0,771 & 0,871 & 0,704 \\
Clan & 0,801 & 0,889 & 0,752 \\
Culture & 0,63 & 0,931 & 0,914 \\
Hierarchy & 0,756 & 0,903 & 0,838 \\
Komunikasi interpersonal & 0,791 & 0,919 & 0,868 \\
Lama bekerja & 1,000 & 1,000 & 1,000 \\
Leadership & 0,759 & 0,949 & 0,935 \\
Market & 0,864 & 0,927 & 0,842 \\
Power relationship & 0,653 & 0,918 & 0,893 \\
Rewards & 0,848 & 0,944 & 0,910 \\
Strategi kepegawaian & 0,852 & 0,945 & 0,913 \\
Struktur organisasi & 0,815 & 0,929 & 0,885 \\
\hline
\end{tabular}


Adapun jika dilihat dari kontribusi leadership dalam culture, nilai koefisien parameternya $-0,000$ serta t-statistik 0,03 , berarti $\mathrm{H} 7$ ditolak. Nilai $-0,000$ berarti bahwa nilai minimum yang sangat kecil dan mendekati 0, dikarenakan SmartPLS hanya bisa mengeluarkan empat digit hasil, dan dengan kata lain leadership hampir tidak memberikan pengaruh pada culture.

Jika mengacu pada penelitian Haakonsson et al. (2008) telah dibuktikan bahwa iklim organisasi dan kepemimpinan harus selaras. Oleh karena itu, terjadinya hal ini dapat disebabkan iklim organisasi yang kurang sesuai dengan leadership style yang ada. Perubahan iklim organisasi selanjutnya tentu dapat mengubah kontribusi leadership dalam pembentukan alignment. Selain itu, dalam mencapai keselarasan perusahaan, perlu juga diciptakan keselarasan antara para manager selaku pemimpin divisi dan melakukan peninjauan (review) secara berkala dalam tiap fase-fase perubahan selanjutnya (Hacker dan Doolen, 2007).

\section{Analisis Pengaruh Power Relationship terhadap Alignment}

Hasil penelitian menunjukkan bahwa pada tingkat kepercayaan $95 \%$, power relationship berpengaruh positif terhadap alignment dengan koefisien parameter 0,581 dan signifikan dengan t-statistik sebesar 2,877 sehingga H8 diterima. Dengan kata lain, power relationship berpengaruh nyata terhadap terbentuknya alignment. Kemudian jika dilihat dari analisis pada indikatornya, hasil menunjukkan bahwa nilai t-statistik rewards dan komunikasi interpersonal yaitu berturutturut 12,585 dan 11,785 lebih besar dari t-tabel, sebaliknya dengan lama bekerja yang nilai t-statistiknya 0,191 dan koefisien parameternya $-0,001$.

Untuk melihat pengaruh power relationship terhadap percepatan culture dalam membentuk alignment, ternyata hasilnya positif namun kurang signifikan sehingga H9 ditolak, atau dengan kata lain tidak terlalu berpengaruh nyata terhadap culture. Dalam penelitian Cober et al. (1998), komitmen dari masingmasing individu dalam perusahaan sangat berpengaruh terhadap terciptanya keselarasan. Jadi, jika hal ini sudah dijalankan, dengan stimulan rewards, komunikasi interpersonal, dan lama bekerja, power relationship juga dapat meningkat.

\section{Pengaruh Culture, Leadership, dan Power Relationship terhadap Alignment}

Dengan menguji pengaruh langsung dan tiap langsung antar variabel, diperoleh bahwa leadership pada studi kasus IKM BBT yang bergerak di bidang tradisional ternyata tidak memberikan pengaruh langsung dalam membentuk culture sehingga kontribusi tidak langsung hampir tidak ada dalam alignment. Di sisi lain, power relationship ternyata memberikan pengaruh positif walau kecil, yaitu sebesar 0,005 dalam pembentukan variable culture secara langsung, dan memberi pengaruh secara tidak langsung pada terciptanya alignment sebesar 0,001. Hasil analisis pengaruh langsung dan tidak langsung antar variabel selengkapnya pada Gambar 4.

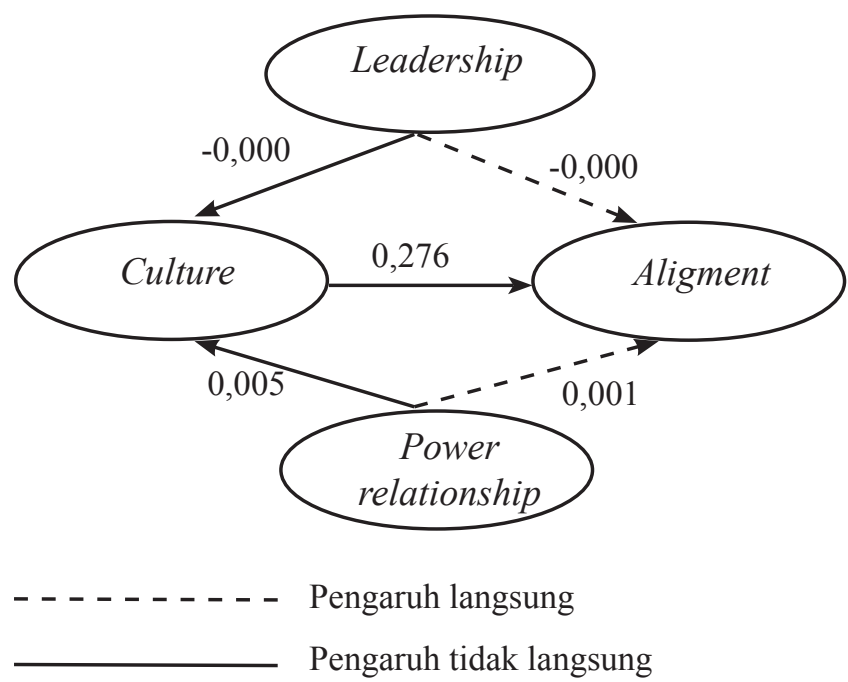

Gambar 4. Hasil analisis pengaruh langsung dan tidak langsung antar variabel

Penelitian ini juga pada akhirnya membuktikan bahwa pendekatan budaya (culture) memberikan kontribusi langsung dalam pembentukan alignment atau dengan kata lain mengurangi ketidakselarasan antar divisi yang terjadi di IKM BBT sebesar 27,6\%. Hal ini sejalan dengan teori keselarasan yang diungkapkan Semler (1997) bahwa budaya (culture) membantu perusahaan dalam mencapai goals atau tujuan yang diharapkan dan sejalan juga dengan penelitian Sosa et al. (2004) bahwa budaya berpengaruh positif pada keselarasan struktural. 
Menurut Adewale dan Anthonia (2013), pendekatan budaya kerja sebagai alat perubahan dalam perusahaan ini dapat dibangun dari membuat standard proses rekrutmen, pelatihan, dan pengembangan para karyawan. Dengan membangun fondasi dari awal proses seleksi, diharapkan karyawan terpilih adalah mereka yang menerima penawaran perusahaan untuk bersedia mematuhi nilai, norma, struktur dan strategi perusahaan. Secara tidak langsung, akan terbina keselarasan dalam perusahaan baik secara horizontal maupun vertikal.

Keselarasan yang baik pada perusahaan akan membawa pada kinerja yang tinggi dan saling terintegrasi dengan prioritas bisnis yang didukung oleh manajemen strategi sumberdaya manusia. Kemudian dengan kompetisi pasar yang semakin tinggi, keselarasan ini tidak akan dapat bertahan kecuali dengan menyeimbangkan norma sosial, undang-undang ketenagakerjaan, dan kebutuhan karyawan. Oleh karena itu, keselarasan pada konteks internal dan eksternal perusahaan harus menjadi salah satu fokus dari strategi perusahaan dalam mencapai tujuannya (Waiganjo, 2012).

\section{Implikasi Manajerial}

Ketidakselarasan akan menuntun kepada kebijakan manajemen strategi perusahaan dalam melakukan perubahan, dan setelah terciptanya keselarasan maka akan tercipta kinerja organisasi atau perusahaan yang baik (Anisimova, 2009). Dengan hasil penelitian yang telah dijabarkan, maka implikasi manajerial yang penulis rekomendasikan kepada IKM BBT yaitu dengan melakukan pendekatan budaya kerja yang cocok diterapkan saat ini dengan fokus pada kreasi dan inovasi (adhocracy) karena budaya kekeluargaan (clan) ternyata berpengaruh negative terhadap budaya kerja.

Setelah dilakukan proses perubahan melalui pendekatan budaya kerja, perlu dilakukan penyesuaian leadership style dalam iklim organisasi yang baru. Hal ini mengacu pada efek leadership yang tidak terlalu berpengaruh pada culture yang diterapkan saat ini dalam membentuk alignment. Menurut Fairholm (2009), bentuk leadership ini dapat dibentuk dengan empat V (values, visions, vectors, dan voice). Dengan penyesuaian leadership style dengan budaya kerja yang tepat diterapkan pada perusahaan, diharapkan kerja dari leadership sebagai katalis dapat mempercepat terciptanya keselarasan.

\section{KESIMPULAN DAN SARAN}

\section{Kesimpulan}

Hasil penelitian ini, dapat disimpulkan bahwa budaya kerja yang dapat menyebabkan terjadinya ketidakselarasan antar divisi di BBT adalah sistem kekeluargaan (clan), sedangkan lamanya bekerja tidak memberikan pengaruh signifikan terhadap terjadinya keselarasan, kepuasan pelanggan atau market memberikan pengaruh kecil terhadap terjadinya keselarasan, dan power relationship dapat digunakan sebagai alat untuk mempercepat terjadinya keselarasan, baik melalui pemberian rewards atau dengan meningkatkan komunikasi interpersonal.

\section{Saran}

Berdasarkan hasil penelitian dan kesimpulan, saran yang penulis ajukan untuk Batik Bogor Tradisiku untuk meningkatkan terjadinya keselarasan antar divisi di BBT adalah dengan memperjelas sistem pemberian rewards sehingga dapat memotivasi karyawan bekerja sesuai porsi dan posisinya, serta meningkatkan komunikasi interpersonal para karyawan antar divisi. Bagi penelitian mendatang, sudut pandang dalam melihat keselarasan yang terjadi di perusahaan dapat dilihat secara keselarasan vertikal (antara manajemen dan karyawan. Selain itu, penelitian selanjutnya dapt mengembangkan Systematic Agreement Theory (SAT) Semler (1997) dengan 4 aspek, yaitu menambah environmental dan performance dengan menghapus Culture. Bagi masyarakat, penilaian terhadap adanya keselarasan atau tidak pada suatu perusahaan bukan berarti menilai kepuasan atau ketidakpuasan terhadap produk perusahaan tersebut.

\section{DAFTAR PUSTAKA}

Adewale OO, Anthonia AA. 2013. Impact of organizational culture on human resource practice: a study of selected Nigerian private universities. Journal of Competitiveness 5(4):115-133.

Anisimova T. 2009. Corporate brand: the company Customer misAlignment and its performance implications. Brand Management 17(7):488503.

Awal D, Klingler J, Rongione N, Stumpf SA. 2006. Issues in organizational Culture change: a 
case study. Journal of Organizational Culture, Communication and Conflict 10(1):79-97.

Cober RT, Hacker S, Johnston CS. 1998. Spiritual Leadership and vision Alignment. ASQ's 52nd Annual Quality Congress Proceedings 917-923.

Dixit GK, Nanda T. 2011. Strategic alignment of organizational culture and climate for stimulating innovation in SMEs. International Journal of Innovation, Management and Technology 2(1):77-85.

Fairholm MR. 2009. Leadership and organizational strategy. The Innovation Journal: The Public Sector Innovation Journal 14(1): 1-16.

Farquhar PH. 2005. Brand Alignment across organizational boundaries. Journal of Brand Management 13(2):96-102.

Gerdhe S. 2012. The policies that affect the extent of the subCultures' Alignment in organization. Journal of Knowledge Management, Economics and Information Technology 8:1-19.

Ghozali I, Latan H. 2015. Konsep, Teknik dan Aplikasi menggunakan Program SmartPLS 3.0. Ed. Ke-2. Semarang: Badan Penerbit Universitas Diponegoro.

Haakonsson DD et al. 2008. How failure to align organization climate and leadership style affect performance. Management Decision 46(3):406432.

Hacker M, Doolen T. 2007. Alignment at the top: a case study investigating this critical factor in project implementation. Engineering Management Journal 19(1): 38-42.
Inabinett JM. 2010. Employee tenure a quantitative correlational study of employees' values and corporate culture [dissertation]. US: University of Phoenix.

Jusri, Idris M. 2012. Batik Indonesia: Soko Guru Budaya Bangsa. Jakarta: Kementrian Perindustrian Republik Indonesia.

Kolina N, Mustamu RH. 2013. Analisis deskriptif strategi bersaing pada perusahaan manufaktur plastik. AGORA 1(1):1-13.

Lundin JF, Norman A. The misAlignment cycle: is the management of your supply chain aligned? International Journal of Physical Distribution and Logistic Management 40(4):277-297.

Semler SW. 1997. Systematic agreement: a theory of organizational alignment. Human Resource Development Quarterly 8(1):23-40.

Sosa M, Eppinger SD, Rowles CM. 2004. The misAlignment of product architecture and organizational structure in complex product development. Management Science 50(12):1674-1689.

Waiganjo EW. 2012. Relationship between strategic human resource management and firm performance of Kenya's corporate organizations. International Journal of Humanities and Social Science 2(10):62-70.

Yang YC, Hsu JH. 2010. Organizational process alignment, culture and innovation. African Journal of Business Management 4(11):22312240. 